\title{
Profitability and Adoption of Watermelon Technologies by Farmers in Moro Local Government of Kwara State, Nigeria
}

\author{
Shehu Folaranmi Gbolahan Yusuf ${ }^{1}$, Francois S. Lategan ${ }^{1} \&$ Idris A. Ayinde $^{2}$ \\ ${ }^{1}$ Department of Agricultural Economics and Extension, University of Fort Hare, South Africa \\ ${ }^{2}$ Department of Agricultural Economics and Farm Management, University of Agriculture Abeokuta Ogun State, \\ Nigeria \\ Correspondence: Shehu Folaranmi Gbolahan Yusuf, Department of Agricultural Economics and Extension, \\ University of Fort Hare, South Africa. E-mail: 201103255@ufh.ac.za
}

Received: November 30, 2012 Accepted: February 5, 2013 Online Published: April 15, 2013

doi:10.5539/jas.v5n5p91 URL: http://dx.doi.org/10.5539/jas.v5n5p91

\begin{abstract}
The study was carried out to determine the adoption rate of watermelon as an alternative crop to the melon the farmers in Moro Local Government Area, Kwara State Nigeria are used to grow traditionally. Unfortunately, melon had remained a poor marketing commodity over a long period of time due to price fluctuation. Data collected were analyzed using descriptive statistics and gross margin. The results indicate that the majority $(80.87 \% ; n=93)$ trained in year 2007 are still active in watermelon cultivation. The adoption of watermelon technologies was influenced by extension packaging styles, compatibility with known methods of melon cultivation, relative advantages, good market price and ready market. Budgetary analysis revealed a profitability of watermelon with gross margin of $\$ 253,850.00$ per hectare. The benefit/cost ratio (BCR) was $3: 1$. The study identified poor extension visit to the farmers after the training. It therefore recommended that the local government should acquire more tractors for hiring to the farmers while subsidy is required in other to reduce the cost of land clearing. Finally, government should as a matter of urgency repair, grade and open up more road network that will facilitating easy transportation of farm produce and reduce cost of transportation.
\end{abstract}

Keywords: watermelon, training, adoption, profitability

\section{Introduction}

Melon (Citrullus colcynthis) also known as honeydew (Mohammed, 2011) is a major crop in Moro Local Government Area (MLGA) of Kwara State, Nigeria. It is an annual crop planted twice in a year, as an early and late season crop due to the bimodal nature of the raining season in the area. Melon belongs to the family of curcurbitaceae and it is planted for its'seed oil (Mohammed, 2011). It is also a major source of different delicacies in food preparations among tribal groups in Nigeria. Melon flesh is bitter, not edible and cannot be cooked (Lagoke et al., 1983). Melon cultivation is common among the small scale farmers and is inter-planted with crops like cassava, maize, yam, pepper (Rice et al., 1986) in order to maximize utilization of the land resources and increase returns from the production systems (Mohammed, 2011). Melon cultivation has not enjoyed a high level of technological improvements such as the use of new hybrid seeds, fertilizer and processing. According to Mohammed (2011) an average yield of $57.70 \mathrm{~kg}$ was obtained on a sole cropping field in Ifelodun Local Government Area Kwara State. Melon cultivation and processing are labor intensive. The matured and harvested fruits are collected on several spots on the farm depending on the farm size. The processing involves breaking the pod, fermentation, scooping the seeds from the pods, washing and sun-drying. Problems associated with marketing of melon include low price and unstable market prices. According to Yusuf et al. (2008), the gross return per hectare (ha) on melon was $\$ 12,638.61$ with the total cost put at $\$ 8,838.74$ on average giving a net farm income of \$3, 799.87 per ha. Ayodele et al. (2007) also reported profit of $\$ 3,619.01$ on a hectare of melon farm in Ibadan. Mohammed (2011) in his findings on the socioeconomic analysis of melon cultivation in Ifelodun Local Government Kwara State, observed the difference between the gross return and the total cost of production that gave a gross margin of N1, 263.81 per ha. As a result of these factors, most farmers could not sell their produce. Many complained of having produce of between three to four years in storage without any hope of immediate sales. Based on these multiple challenges, Fayolam Farms situated at Bielesin village, via Bode Saadu, Moro LGA of 
Kwara State conducted a simple survey in 2007 in order to introduce an alternate crop to the farmers that could bring in the needed income for improved livelihood.

Watermelon (Citrullus lanatus L) was chosen after considering several factors within the framework of the diffusion process of new technology that must include relative advantage, compatibility, complexity, triability and observability (Rogers, 2003). The common shared problem, poor marketing and price fluctuation under the social system of diffusion (Rogers, 2003) was addressed as joint problems to be solved towards providing better marketing opportunities for an alternate crop in watermelon. In Nigeria, watermelon grows well both in the humid and drier savanna agro ecologies. The largest production of the crop comes from the northern part of Nigeria where a suitable agro ecology is found (Adekunle et al., 2007). Moro Local Government Area (MLGA) of Kwara State is located in the humid area suited for watermelon cultivation. Watermelon is relished by many people across the world as a fresh fruit (Adekunle et al., 2007). The fruit is $93 \%$ water, with small amounts of protein, fat, minerals, and vitamins (Namdari, Mohammedi, \& Mobtaker, 2011). Watermelon is known to be low in calories, it contains Vitamins $\mathrm{C}$ and Awhich helps address night blindness, eye problems, dry skin, eczema and psoriasis (Bendich \& Olson, 1989). It contains potassium which is believed to help in the control of blood pressure and possibly prevent stroke (Adekunle et al., 2007).

The diffusion of the watermelon technologies to the farmers was a tripartite arrangement involving Fayolam Farms, the initiator that provided the logistics, fertilizers and demonstration plot, a seed company that provided different varieties of watermelon seeds adapted to the ecological zone and agro-allied company that provided the herbicides, pesticides and knapsack sprayers. The training workshop was conducted on the 18-19 March, 2007.

Farmers were trained with the following modules (a) Land preparation for watermelon cultivation using minimum tillage; (b) Pre and post emergence weed control methods using different types of herbicides; (c) planting (distance and number of seeds per hole); (d) disease and pest control; (e) fertilizer application; (f) How to use a knapsack sprayer, handling and maintenance; (g) harvesting; (h) storage and; (i) marketing tips. The training was practically oriented and conducted in Yoruba language, being the local language. Three years after the introduction of the watermelon technologies, the training is now evaluated to:

1) Examine the socioeconomic characteristics of the respondents;

2) To compare the farm size holding of farmers in 2007 and 2010;

3) Determine the profitability of watermelon production by the respondents in the study area.

\section{Methodology}

\subsection{Study Area}

The Kwara state lies between latitudes $7^{\circ} 45^{\prime} \mathrm{N}$ and $9^{\circ} 30^{\prime} \mathrm{N}$ and longitudes $2^{\circ} 30^{\prime} \mathrm{E}$ and $6^{\circ} 25^{\prime} \mathrm{E}$ and covers a total land area of about 332,500 square kilometers (Paul \& Oluwasina, 2011). The state has a population of about 2.37 million people (National Population Commission (NPC), 2008). It is exclusively in the hinterlands. The weather is humid tropical (Jimoh \& Adeoye, 2011). The state shares boundary with Ondo, Oyo, Osun, Niger and Kogi States in Nigeria and an international border with the Republic of Benin along its northwestern part (Kwara State Government (KWSG), 2003). The mainstay of the state's economy is agriculture. The study area is within Lanwa District in Moro Local Government Area (LGA). Moro LGA was created out of the Ilorin Native Authority in 1976 (KWSG, 2012). The headquarters is at Bode Saadu which is about eighty five kilometers from Ilorin, the state capital. Moro LGA is rural, mostly comprised of local populations with low literacy level and low income (Ajibade et al., 2005). It has an area of $3272 \mathrm{~km}$ square and a population of 108,792 at the 2006 census. It is populated by rural farmers. The local government area is endowed with good climatic conditions, sizable expanse of arable and rich fertile soils. The vegetation which is mainly wooded guinea savannah, well suited for the production of a wide variety of staples like yam, melon, groundnut, cassava, maize, cowpea, fruits and vegetables. Rice, sugarcane, locust beans, shea butter trees, cashew, and mango are also significant cash crops. Common to the area are local poultry, guinea-fowls, goats rearing mostly by the women and cattle by immigrant Fulani and Bororo who are settled amongst the people. 


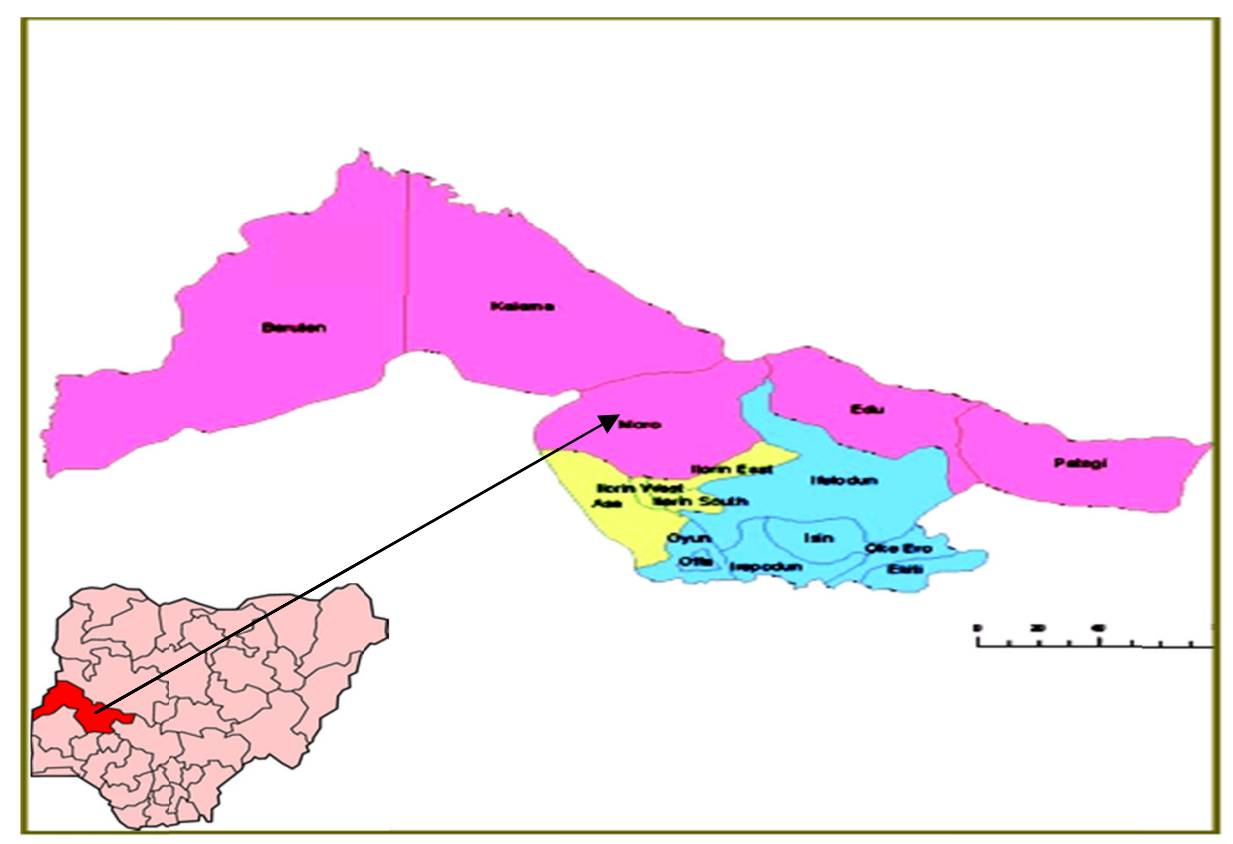

Figure 1. Showing the maps of Kwara State and Nigeria beside. Arrowed is the study area

\subsection{Sample Size}

The population consisted of all 115 farmers trained in watermelon technologies in the year 2007, who were drawn from eight villages that included: Fallah, Bielesin, Olokiti, Gata, Bode-Saadu, Alagbon, Lasaki, and Olokiti-Nla. Data (through structured interview schedule) was received and analyzed from a sample of 93 farmers representing $80.87 \%$ response rate. Purposive sampling procedure was used since they were known target respondents. The instrument was structured interview schedule that solicited information from the respondents on the socioeconomic profile of the watermelon farmers, age, gender, marital status, educational status, occupation, farming experience, farm size and household size.

The second part of the questionnaire solicited information on the cultivation practices by the farmers on watermelon after the training, the size of farmland in 2007 and 2010, the challenges in cultivation practices, quantity of inputs used (seed, fertilizer, herbicides, pesticides), labor cost, yield per hectare (number of fruits/ balls), and revenue realized per hectare. The instrument was field tested for content and face validity by extension staff of the Kwara State Agricultural Development Programme (KWSADP). In order to obtain a high measure of internal consistency to determine the validity and reliability of the questionnaire, the instrument was pilot tested with watermelon farmers located at Kainji. The items that were found to be highly reliable and valid were used. The level of reliability of the instrument was calculated using Cronbach's alpha coefficient $(\alpha=0.91)$.

Data collected were analyzed using descriptive statistics which include frequency counts, percentages and mean scores. Farm budget analysis was used to estimate the cost of production, total revenue and gross margin for the farmers. The Gross margin, total cost and Net farm income were calculated using the following formula

$$
\begin{aligned}
\mathrm{GM} & =\mathrm{TR}-\mathrm{TVC} \\
\mathrm{NFI} & =\mathrm{GM}-\mathrm{FC}
\end{aligned}
$$

Where

$\mathrm{GM}=$ Gross margin, $\mathrm{TR}=$ Total revenue, $\mathrm{TVC}=$ Total variable cost;

$\mathrm{NFI}=$ Net farm income, $\mathrm{FC}=$ Fixed cost;

Depreciation on farm tools was calculated using the straight line method as follows:

Depreciation $=($ cost of purchase - salvage value $) /$ usable life . 


\section{Results and Discussion}

\subsection{Socioeconomic Characteristics of Respondents}

Table 1 shows the socioeconomic characteristics of the respondents. The result indicates that the majority of the respondents are male $(75.26 \% ; \mathrm{n}=70)$ while female $(24.74 \% ; \mathrm{n}=23)$ are less. This follows the traditional pattern that the male is dominant in the farming system in that community. The result also shows that the majority of the respondents $(76.4 \% ; \mathrm{n}=71)$ are in the age bracket of less than thirty to fifty years which is active with few $(23.07 \% ; \mathrm{n}=22)$ belonging to fifty-one years and above. The mean age was 37.5 years indicating that the majority are able bodied men and women who are still in their active year. Age plays significant role in farming as it determines the strength of the farmers' ability to carry out tedious and rigorous work as defined by some activities in watermelon cultivation, for example, mounting of knapsack sprayer at the back. The majority $(77.4 \% ; \mathrm{n}=72)$ were married with a very low proportion $(11.83 \% ; \mathrm{n}=11)$ as either single or $(10.78 \% ; \mathrm{n}=10)$ widowed. The number of households of the respondents indicates that majority $(66.68 \% ; n=62)$ are having household population of less than five to eight with the mean value of 6.65 . The majority $(78.49 \% ; n=73)$ of the respondents had gone through one form of formal education at various levels of primary to tertiary while very few $(21.51 \% ; n$ $=20$ ) did not have any form of formal education. It has been confirmed that education plays significant role in the adoption rate of technologies by creating positive mental attitudes (Benor et al., 1997). Adetiba (2005) and Kehinde (2005) also confirm that education was key to enhanced productivity among farming households in the humid forest, dry savannah and moist savannah agro-ecological zones of Nigeria.

\subsection{Farm Size Holding of Farmers in 2007 and 2010}

Figure 1 showed that between 2007 and 2010, the majority $(99.14 \% ; n=114)$ of the respondents who were clustered on farmland sizes ranging from 0.1 to 1 hectares (ha) (male, $25.2 \% ; n=29$, female $20 \% ; n=23$ ), 1.01 2ha (male, $40.87 \% ; \mathrm{n}=47$, female $4.3 \% ; \mathrm{n}=5)$ and $2.01-3$ ha $($ male $8.7 \% ; \mathrm{n}=10)$ were able to increase their farmland sizes by various hectarage. In 2010 , the farm land sizes indicates 0.1 to 1 ha (male, $9.68 \% ; \mathrm{n}=9$, female, $11.83 \% ; \mathrm{n}=11), 1.01-2$ ha (male, $30.10 \% ; \mathrm{n}=28$, female $9.68 \% ; \mathrm{n}=9$ ), $2.01-3$ ha (male, $20.43 \% ; \mathrm{n}=19$, female, $3.03 \% ; \mathrm{n}=3$ ), 3.01-4 ha (male 12.9\%; $\mathrm{n}=12$ ), $4.01-5$ ha and 5.01 ha and above (male $1.07 \% ; \mathrm{n}=1$ each). The gradual expansion in farmland sizes could be attributed to the successes recorded by the farmers in terms of market availability and profits realized from the watermelon cultivation. Meanwhile, of the total 115 farmers trained in year 2007 , the majority $(80.87 \% ; n=93)$ are still active in growing watermelons indicating the acceptance of the watermelon cultivation as an alternative to melon cultivation.

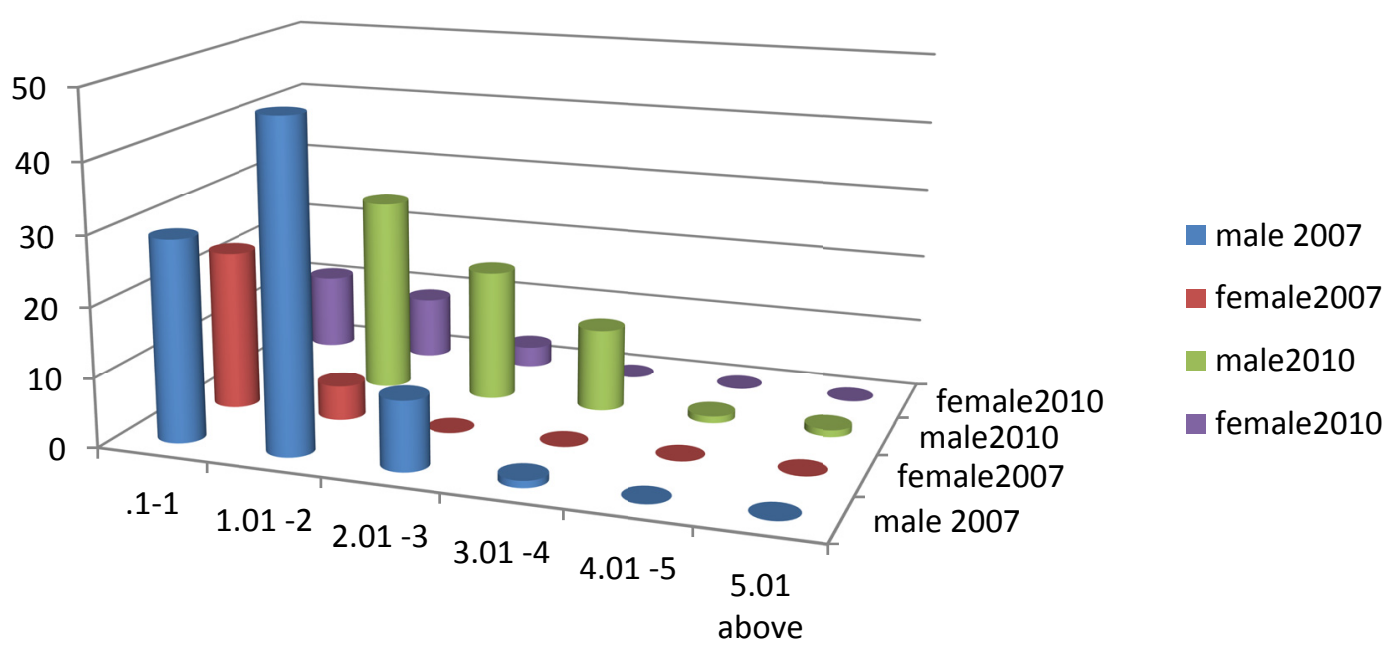

Figure 2. Farmland size holding of farmers in 2007 compared with 2010 on watermelon cultivation 
Table 1. socioeconomic characteristics of respondents in the study area $\mathrm{N}=93$

\begin{tabular}{|c|c|c|c|}
\hline Items & Frequency & Percentage & \\
\hline Male & 70 & $75.26 \%$ & \\
\hline Female & 23 & $24.74 \%$ & \\
\hline Total & 93 & $100 \%$ & \\
\hline \multicolumn{4}{|l|}{ Age according to gender } \\
\hline Age & Male & Female & Mean \\
\hline$\leq 30$ & $17(18.3 \%)$ & $8(8.6 \%)$ & \\
\hline $31-40$ & $20(21.5 \%)$ & $6(6.5 \%)$ & \\
\hline $41-50$ & $16(17.2 \%)$ & $4(4.3 \%)$ & \\
\hline $51-60$ & $12(12.9 \%)$ & $4(4.3 \%)$ & \\
\hline$>60$ & $5(5.4 \%)$ & $1(1.07 \%)$ & 37.5 years \\
\hline Total & $70(75.26 \%)$ & $23(24.74 \%)$ & \\
\hline \multicolumn{4}{|c|}{ Farming experience according to gender } \\
\hline Farming experience & Male & Female & Mean \\
\hline$\leq 5$ years & $32(34.4 \%)$ & $4(4.3 \%)$ & \\
\hline $6-10$ years & $13(13.98 \%)$ & $6(6.5 \%)$ & \\
\hline $11-15$ years & $6(6.45 \%)$ & $4(4.3 \%)$ & \\
\hline $16-20$ years & $15(16.12 \%)$ & $2(2.15 \%)$ & \\
\hline$>20$ years & $4(4.3 \%)$ & $7(7.52 \%)$ & 9.89 years \\
\hline \multicolumn{4}{|l|}{ Educational status } \\
\hline No formal education & $9(9.68 \%)$ & $11(11.83 \%)$ & \\
\hline Primary education & $19(20.43 \%)$ & $8(8.6 \%)$ & \\
\hline Junior secondary school & $20(21.50 \%)$ & $2(2.14 \%)$ & \\
\hline Senior secondary school & $17(18.3 \%)$ & $2(2.14 \%)$ & \\
\hline Tertiary education & $4(4.3 \%)$ & - & \\
\hline Total & $70(75.26 \%)$ & $23(24.70 \%)$ & \\
\hline \multicolumn{4}{|l|}{ Marital status } \\
\hline Married & $52(55.91 \%)$ & $20(21.50 \%)$ & \\
\hline Single & $11(11.83 \%)$ & - & \\
\hline Widowed & $7(7.52 \%)$ & $3(3.22 \%)$ & \\
\hline Total & $70(75.26 \%)$ & $23(24.70 \%)$ & \\
\hline Household size & & & Mean \\
\hline$\leq 5$ & $29(31.18 \%)$ & & \\
\hline $6-8$ & $33(35.5 \%)$ & & \\
\hline $9-10$ & $17(18.3 \%)$ & & \\
\hline$>10$ & $14(15.03 \%)$ & & 6.65 \\
\hline Total & 93 & & \\
\hline Occupation & Male & Female & \\
\hline Farming & $16(17.2 \%)$ & $08(8.60 \%)$ & \\
\hline Non-farming & $10(10.8 \%)$ & $04(4.30 \%)$ & \\
\hline Trading & $07(7.52 \%)$ & $11(11.83 \%)$ & \\
\hline Okada rider & $26(27.95 \%)$ & - & \\
\hline Civil service & $05(5.40 \%)$ & - & \\
\hline Others & $06(6.50 \%)$ & & \\
\hline Total & $70(75.26 \%)$ & $23(24.70 \%)$ & \\
\hline \multicolumn{4}{|l|}{ Extension visit } \\
\hline Yes & $23 \%$ & & \\
\hline No & $77 \%$ & & \\
\hline
\end{tabular}


Table 2. Pattern of cropping practices used by the respondents $(\mathrm{N}=93)$

\begin{tabular}{|c|c|c|}
\hline Characteristics & Categories & Percentage \\
\hline \multirow[t]{2}{*}{ Cropping system adopted } & Sole cropping & 62.6 \\
\hline & Inter- cropping & 37.4 \\
\hline \multirow[t]{3}{*}{ Inter-cropping system } & Watermelon and cassava & 50 \\
\hline & Watermelon and maize & 41.18 \\
\hline & Watermelon and other crops & 8.82 \\
\hline \multirow{5}{*}{$\begin{array}{l}\text { The reasons adduced for } \\
\text { inter-cropping }\end{array}$} & Reduced risk of plant failure & 73.6 \\
\hline & Increase in income & 81.9 \\
\hline & Weed control & 48.5 \\
\hline & Improve soil fertility & 53.9 \\
\hline & Effective land use & 42.4 \\
\hline \multirow{3}{*}{$\begin{array}{l}\text { Reasons for adopting } \\
\text { sole-cropping }\end{array}$} & Good management & 73.6 \\
\hline & More profit & 51.3 \\
\hline & Convenient in farm management & 69.8 \\
\hline \multirow{2}{*}{$\begin{array}{l}\text { Watermelon variety } \\
\text { planted }\end{array}$} & Sugar baby & 94.9 \\
\hline & Charleston Gray & 5.1 \\
\hline \multirow[t]{8}{*}{ Cultural practices } & Direct seeding & 100 \\
\hline & Seedling & - \\
\hline & Weed control & \\
\hline & Manual & 39.5 \\
\hline & Use of herbicides & 60.5 \\
\hline & Pest and diseases control & \\
\hline & Chemical control & 87.3 \\
\hline & Non use of chemical control & 12.7 \\
\hline \multirow[t]{2}{*}{ Labor } & Family labor & 41.93 \\
\hline & Hired labor & 58.06 \\
\hline
\end{tabular}

Source: Field survey 2011.

Table 2 shows that the majority $(62.6 \% ; \mathrm{n}=58)$ planted watermelon as sole crop while the remaining $(37.4 \% ; \mathrm{n}=$ $35)$ practiced intercropping of watermelon with maize $(41.18 \% ; n=14)$, cassava $(50 \% ; n=18)$, and other minor crops $(8.82 \% ; \mathrm{n}=3)$. The popularity of sole cropping may be as a result of the training which emphasized sole cropping practices. The respondents also gave the following reasons for engaging in sole cropping to include better management $(73.6 \% ; n=43)$, increased profit $(51.3 \% ; n=30)$ and ease of farm management $(69.8 \% ; n=40)$. Reasons for inter-cropping include: reduced risk of crop failure $(73.6 \% ; \mathrm{n}=26)$, lead to increase in income $(81.9 \%$; $\mathrm{n}=29)$, weed control $(48.5 \% ; \mathrm{n}=17)$, improves soil fertility $(53.9 \% ; \mathrm{n}=19)$, and effective land resource use $(42.4 \% ; n=15)$. Sugar baby variety was the most popular $(94.9 \% ; n=87)$ to a Charleston Gray variety $(5.1 \% ; n=$ 6). The reasons for this may be attributed to its characteristics of big size, sweetness, ability to store very well and command a high price in the market.

The cultural methods employed by the respondents reflected the training pattern that they were taken through with few yet to adopt the entire technologies. All respondents made use of direct seeding $(100 \% ; n=93)$. Weed control was mostly done by the use of herbicides $(60.5 \% ; n=56)$ and manual $(39.5 \% ; n=37)$. Manual weeding demanded an average of 2-3 weeding before harvesting. Manual weeding is mostly affected by accidental cutting of vines, destruction of flowers and stepping on young fruits. Pest and disease control was mostly done by the use of chemical $(87.3 \% ; n=81)$ and non -utilization of chemical control method $(12.7 \% ; n=12)$. The use of chemical control of pest and diseases is needed because of the high level of susceptibility of watermelon to diseases and 
pests and this has to be done on a weekly basis at the onset of fruiting. The majority $(73 \% ; \mathrm{n}=68)$ of the respondents owned knapsack sprayers while others rent from colleagues. The majority $(58.06 \% ; n=54)$ of the respondents relied on hiring labor for their farm operations while others $(41.93 \% ; n=39)$ depend on family labor. This result is closely in agreement with the findings of Ala and Bala (2011) in their study on the profitability of watermelons production and marketing in Kirfi local government areas of Bauchi State, Nigeria, which revealed that $60 \%$ of the labor employed was hired while $40 \%$ was family labor. Meanwhile, respondents reported low $(23 \%)$ visit by extension agents, thus contributing to the inadequacy of solving their technical challenges.

Table 3. Average costs and returns per hectare for sole watermelon

\begin{tabular}{lcl}
\hline Items of costs/returns & Total (\$) & \% of TVC \\
Gross return ( $)$ & $377,500.00$ & 100 \\
\hline Variable cost ( $)$ & $28,500.00$ & 23.05 \\
Land clearing and preparation & $3,500.00$ & 2.8 \\
Stumping and packing & $4,250.00$ & 3.44 \\
Plow & $5,500.00$ & 4.45 \\
Seeds & $5,000.00$ & 4.04 \\
Planting & $12,300.00$ & 9.95 \\
Herbicide and application & $13,300.00$ & 10.77 \\
Fertilizer and application & $6,300.00$ & 5.1 \\
Insecticides and application & $8,500.00$ & 6.9 \\
Harvesting & $12,500.00$ & 10.11 \\
Transportation & $123,650.00$ & 100 \\
Total variable cost (TVC) (\$) & $253,850.00$ & \\
Gross margin (TR-TVC) & & \\
\hline Fixed cost & $4,500.00$ & \\
Land rent & $3,724.00$ & \\
Depreciation & $245,626.00$ & \\
Net margin /ha or Net Farm Income & & \\
(GM-FC) & $3: 1$ & \\
\hline Benefit / Cost Ratio (BCR) & & \\
\hline
\end{tabular}

Source: Field survey 2011.

\subsection{Costs and Return Structure}

Table 3 represents the average cost and returns per hectare for sole cropping of watermelon. The total variable cost was $\$ 123,650.00 /$ ha with a gross margin generated at $\$ 253,850.00$. The benefit cost ratio was 3:1 indicating high profitability of watermelon cultivation in the area. This is a strong indication why many of the farmers are now opting for watermelon cultivation after the training. There was no report of poor marketing as compared to melon where most farmers are having melon in storage for up to three to four years due to price fluctuation and nonavailability of buyers.

The total cost structure indicates that land preparation (23.05\%), herbicides and application (9.95\%), fertilizers and application (10.77\%), and harvesting (6.9\%) accounted for high variable cost. These variables included cost of hiring labor. It implies that hired labor is still highly required for efficiency in any small-holding farming system in Nigeria. Transportation cost (10.11\%) was also significant.

\section{Conclusions and Recommendations}

From the results obtained from this study, it can be concluded that watermelon production is profitable in this situation and the adoption rate of the watermelon technologies was high and encouraging. The contributory factors to the change by the melon farmers in watermelon production could be attributed to the availability of inputs, markets and the profit margin that accrued to the farmers. These indicate compelling factors / drive for farmland expansion of the farmers. Based on the results from the study, the following recommendations are made: 
1) That the local government should aquire more tractors for hiring to the farmers while further subsidy is required in other to reduce the cost of land clearing.

2) Government should as a matter of urgency repair, grade and open more access roads to reduce the cost of transporting agricultural goods.

\section{References}

Adekunle, A. A., Fatunbi, A. O., Adisa, S., \& Adeyemi, O. A. (2007). Growing watermelon commercially in Nigeria: An illustrated guide. USAID ICS-NIGERIA and IITA. Retrieved October 5, 2012, from http://www.fao.org/sd/erp/toolkit/BOOKS/watermelon_illust_guidebook.pdf

Adetiba, T. O. (2005). Productivity and technical efficiency among small scale fish farmers in Ibadan metropolis. Unpublished M. Sc thesis. Department of Agricultural Economics, University of Ibadan, Nigeria.

Ajibade, L. T., Fatoba, P. O., Raheem, U. A., \& Odunuga, B. A. (2005). Ethnomedicine and primary health care in Ilorin, Nigeria. Indian Journal of Traditional Knowledge, IJTK, 4(2), 150-158.

Ala, A. L., \& Bala, M. I. (2011). Costs and Returns Analysis of Watermelon Production in Kebbi State, Nigeria. Proceedings of the 25th Farm Management Association of Nigeria (FAMAN) Conference. 5th - 8th September, 2011, Akure, Nigeria.

Ayodele O. J., Oladapo M. O., \& Omotoso, S. O. (2007). Fertilizer Sector Liberalization: Effects on the Profitability of Nitrogen Fertilizer Application in 'Egusi', Okra and Tomato Production in Nigeria. International Journal of Agricultural Research, 2, 81-86. http://dx.doi.org/10.3923/ijar.2007.81.86

Bendich, A., \& Olson, T. A. (1989). Biological Actions of Carotenoids. FASEB Journal. Retrieved from http://pi.oregonstate.edu/infocenter/phytochemicals/carotenoids/

Benor, D., Harrison, I. Q., \& Barter, M. (1997). Agricultural Extension: The training and Visit System. Washington, DC. The World Bank. Retrieved from http://www.kwarastate.gov.ng/index.php?option=com_content\&task=view\&id=103\&Itemid=103

Jimoh, H. I., \& Adeoye, A. O. (2011). Application of Geographic Information System to the Effects of Climatic Variability on Sustainable Agricultural Production in Kwara State of Nigeria. Global Journal of Human Social Science, 11(5).

Kehinde, L. K. (2005). Efficiency of sawn wood production and distribution in Ondo State, Nigeria. Unpublished PhD Thesis. Department of Agricultural Economics, University of Ibadan, Nigeria.

Kwara State Government. (2003). Baseline Agriculture Survey/Gap Analysis. Kwara State Ministry of Agriculture.

Kwara State Government. (2012). Moro Local government.

Lagoke, S. T. D., Chadra-Singh, D. T., \& Ologunde, O. O. (1983). The reemergence of chemical weed control in Egunsi melon in the Southern Guinea Savanna of Nigeria. J. Crop-Prot., 2(2), $235-242$. http://dx.doi.org/10.1016/0261-2194(83)90050-9

Mohammed, B. T. (2011). Socioeconomic analysis of melon production in Ifelodun Local Government Area, Kwara State, Nigeria. Journal of Development and Agricultural Economics, 3(8), 362-367.

National Population Commission. (2008). Population Census Report. National Population Commission of Nigeria. Abuja.

Oguntola, S. (2006). Watermelon: Hidden gem yet to be discovered. Nigerian Tribune Thursday 13 th July, 2006. In A. Ya'u, B. A. Mahmoud, \& H. Kubura (Eds.), Profitability of Water Melon Production and Marketing in Kirfi Local Government Area of Bauchi State, Nigeria. Proceedings of the 25th Farm Management Association of Nigeria (FAMAN) Conference, 5th - 8th September, 2011, Akure, Nigeria.

Paul, I. I., \& Oluwasina, O. (2011). Rainfall Characteristics and Maize Yield in Kwara State, Nigeria. Indian Journal of Fundamental and Applied Life Sciences. Retrieved May 16, 2012, from http://www.cibtech.org/jls.htm

Rice, R. P., Rice, L. W., \& Tindall, H. F. (1986). Fruit and Vegetable production in Africa. London and Basigstoke: Macmillan Publishers Limited.

Rogers, E. M. (2003). Diffusion of innovation (5th ed.). In I. Sahin (Ed.), Detailed review of Rogers' diffusion of innovation theory and educational technology-related studies based on Rogers' theory. The Turkish online Journal of Educational Technology. TOJET 5(2). New York: Free press. 
Namdari, M., Mohammedi, A., \& Mobtaker, H. G. (2011). Assessment of energy requirements and sensitivity analysis of inputs for watermelon production in Iran. International Journal of Plant, Animal and Environmental Sciences, 1(1).

Yusuf, O., Sanni, S. A., Ojuekaiye, E. O. \& Ugbabe, O. O. (2008). Profitability of 'egusi' melon (citrullus lanatus thunb. Mansf) production under sole and mixed cropping systems in Kogi State, Nigeria ARPN Journal of Agricultural and Biological Science, 3(2). 